\title{
Haematological Effects of Paraquat Dichloride on Clarias Gariepinus.
}

\author{
E.N. Ogamba*; Gijo, A.H. and E.I. Seiyaboh \\ Department of Biological Sciences, Niger Delta University, Wilberforce Island, Bayelsa State, Nigeria.
}

\begin{abstract}
Haematological (Hb, PCV, WBC, $N$ and L) effects of Paraquat Dichloride on Clarias gariepinus were studied. Thirty - eight juvenile fishes of Clarias gariepinus (mean weight, $149.21^{ \pm} 1.44 \mathrm{~g} \mathrm{SD}$; mean length, $\left.26.25^{ \pm} 2.10 \mathrm{~cm} S D\right)$ were exposed to Chronic and acute levels of Paraquat Dichloride, an organophosphate pesticide. The range of concentrations used for the definitive test were 0.00ppm, 0.05ppm, 0.10ppm, 0.20ppm, $0.30 \mathrm{ppm}$ and $0.40 \mathrm{ppm}$. There were fluctuations in the blood parameters. Haemoglobin and PCV had their highest values $43.1^{ \pm} 0.00 S D$ and $33.6^{ \pm} 0.24 S D$ respectively at $0.4 p p m$ concentration of the toxicant. WBC had the least value of $93^{ \pm} 0.00$ SD. Lymphocytes on the other hand increased steadily with increase in the concentration of the toxicant ranging from $85.70^{ \pm} 0.17 \mathrm{SD}$ at $0.00 \mathrm{ppm}$ of toxicant to $88.30^{ \pm} 0.17 \mathrm{SD}$ at $0.40 \mathrm{ppm}$ of toxicant. Neutrophils did not show any definite pattern of variation. The results showed that Paraquat dichloride had profound effect on the haematological parameters of Clarias gariepinus.
\end{abstract}

Key words: Clarias gariepinus, paraquat dichloride, Haematological parameters (Hb,PCV, WBC, $N$ and L.).

\section{Introduction}

Paraquat dichloride is the trade name for $\mathrm{N}, \mathrm{N}$ - dimethyl - 4, 4- bipyridinium Chloride, one of the most widely used herbicides in the world. It is poisonous to humans, having toxic effects on the liver, lungs and kidneys if ingested. Paraquat is not easily broken down and can persist in the environment adsorbed to soil particles. Since Paraquat is extensively applied in agriculture for weeds control in Nigeria, it is pertinent to study its hazardous effects on the aquatic system. It is assumed that the residue might affect fish as a result of run-off into the water body.

The application of haematological technique in fish culture for toxicological research in environmental monitoring and fish health studies is becoming well established. Some published work on pesticide induced haematological changes in fish include; Kori-Siakpere (1985); Das and Mukherjee (2000); Adeyemo et al. (2005); Patnaik and Patra (2006). They highlighted the possibility that studies on fish blood might reveal conditions within the body of fish long before there is any outward appearance of symptoms. The catfish Clarias gariepinus is widely distributed in Africa, Syria, Southern and Western Asia and belongs to the Claridae family. Clarias gariepinus is an ecologically important and commercially valued fish for the Nigeria fishing industry (Ita, 1980). These mud fish are frequently and widely cultured in ponds and they also occur freely in Nigerias natural fresh waters.

The objective of this project is to evaluate the effect of Paraquat dichloride on the haematological properties of Clarias gariepinus.

\section{Materials And Methods}

Thirty - eight Juvenile Clarias gariepinus (mean weight; $149.21^{ \pm} 1.44 \mathrm{~g}$ SD) mean length; $26.25^{ \pm}$ $2.10 \mathrm{~cm} \mathrm{SD)}$ were obtained from a private fish farm at aquaculture research center, Aluu, Port Harcourt, Rivers State. They were transported in fifty litres trough whose mouth was covered by a net by car to the department of Biological sciences laboratory, Niger Delta University, Wilberforce Island, Bayelsa State, Nigeria. On arrival the fish were acclimated individually in circular aquaria for seven days. The top of the aquaria were covered to prevent escape of fish. The net had a slit at the middle for cleaning the aquaria. The water was changed daily and the aquaria washed with a piece of foam. The fish were fed once a day with a $35 \%$ crude protein diet at $1 \%$ biomass daily $(09.00-10.00 \mathrm{hrs})$.

A range finding test was carried out using the toxicant Paraquat dichloride (obtained from Diazenhoff Nigeria limited, Port Harcourt) five concentrations were prepared from the original solution $(250 \mathrm{~g} 1)$. The trial test was arranged in six groups of $0.00,0.5,0.10,0.20,0.30$, and $0.40 \mathrm{ppm}$. Three fishes were exposed to each concentration of Paraquat dichloride. The introduction of the toxicant was done with the aid of pipette and suckers. The purpose of the test was to determine the range of concentration to be used for the definitive test.

Sub-lethal concentrations for the definitive test was done based on the range finding test. The concentrations were $0.10,0.20,0.30$ and $0.40 \mathrm{ppm}$ as in the range finding test. 
There were six treatment levels with four replicates. Four fishes were introduced individually into each aquarium containing the various concentrations of the toxicant for the period of 7 days. Thirty litres of solution was used and fish were fed as in the activation period. The test solution was renewed daily after washing the aquarium. The water was filled to 25 litres point before the introduction of the toxicant, after which the water was made up to the thirty litres mark.

Physicochemical qualities of Aquaria water; Temperature, conductivity, $\mathrm{pH}$, salinity, dissolved oxygen (DO), alkalinity and turbidity were measured according to the standard methods prescribed in APHA (1998).

\section{SAMPLE COLLECTION AND ANALYSIS}

At the end of the experiment, blood samples were collected from the caudal vein of each fish using separate heparinzed disposable syringes and hypodermic needles. Haemoglobin $(\mathrm{Hb})$ content, leucocytes (WBC), Neutrophils (N) and Lymphocytes were determined using the method described by Svobodova et al. (1991), packed cell volume (PCV) was measured after centrifugation at $300 \mathrm{rpm}$ for 10 minutes. Data obtained were analyzed statistically using one way analysis of variance at $95 \%$ probability and means separated by Duncans multiple range test at $95 \%$ probability (wahua,1999).

\section{Result}

The mean values of the physicochemical properties of the water in the exposed aquaria are presented in Table 1. The fluctuation in the mean values of the water quality parameters were comparable $(\mathrm{P}>0.05)$ to the control values and with no clear relationship displayed between the parameters and the concentration of Paraquat dichloride. However, dissolved Oxygen (DO) was the only exception with the mean values decreasing $(\mathrm{P}<0.05)$ with increase in the concentration of Paraquat. The DO value for the control was $\left(7.21^{ \pm} 0.02 \mathrm{mg} 1\right.$, while the DO value at the highest concentration of Paraquat $(0.40 \mathrm{ppm})$ dropped to $5.38^{ \pm} 0.01 \mathrm{mg} 1$.

Table 1: physico-chemical parameters of the exposed aquaria.

\begin{tabular}{|l|l|l|l|l|l|l|}
\hline $\begin{array}{l}\text { Conc. Of } \\
\text { paraquat } \\
(\mathrm{ppm})\end{array}$ & $\mathrm{pH}$ & Conductivity & Temperature & Turbidity & $\begin{array}{l}\text { Dissolved } \\
\text { Oxygen }\end{array}$ & $\begin{array}{l}\text { Alkalinit } \\
\mathrm{y}\end{array}$ \\
\hline 0.00 & $6.27^{ \pm} 0.08^{\mathrm{a}}$ & $99.5^{ \pm} 21.46^{\mathrm{a}}$ & $26.00^{ \pm} 0.00^{\mathrm{a}}$ & $0.25^{ \pm} 0.45^{\mathrm{ab}}$ & $7.20^{ \pm} 0.02^{\mathrm{a}}$ & $\begin{array}{l}12.33^{ \pm} 0 . \\
78^{\mathrm{c}}\end{array}$ \\
\hline 0.05 & $6.37^{ \pm} 0.07^{\mathrm{a}}$ & $105.80^{ \pm} 80.00^{\mathrm{a}}$ & $26.10^{ \pm} 0.32^{\mathrm{a}}$ & $0.20^{ \pm} 0.42^{\mathrm{ab}}$ & $6.28^{ \pm} 0.05^{\mathrm{ab}}$ & $\begin{array}{l}12.40^{ \pm} 0 . \\
84^{\mathrm{c}}\end{array}$ \\
\hline 0.10 & $6.35^{ \pm} 0.07^{\mathrm{a}}$ & $108.75^{ \pm} 20.70^{\mathrm{a}}$ & $26.10^{ \pm} 0.32^{\mathrm{a}}$ & $0.50^{ \pm} 0.57^{\mathrm{a}}$ & $6.61^{ \pm} 0.05^{\mathrm{ab}}$ & $\begin{array}{l}15.25^{ \pm} 0 . \\
96^{\mathrm{ab}}\end{array}$ \\
\hline 0.20 & $6.35^{ \pm} 0.11^{\mathrm{a}}$ & $136.12^{ \pm} 14.04^{\mathrm{a}}$ & $26.13^{ \pm} 0.35^{\mathrm{a}}$ & $0.50^{ \pm} 0.58^{\mathrm{a}}$ & $6.17^{ \pm} 0.01^{\mathrm{bc}}$ & $\begin{array}{l}14.88^{ \pm} 0 . \\
99^{\mathrm{ab}}\end{array}$ \\
\hline 0.30 & $6.20^{ \pm} 0.11^{\mathrm{a}}$ & $128.00^{ \pm} 16.36^{\mathrm{a}}$ & $26.00^{ \pm} 0.00^{\mathrm{a}}$ & $0.18^{ \pm} 0.40^{\mathrm{b}}$ & $5.35^{ \pm} 0.03^{\mathrm{c}}$ & $\begin{array}{l}17.09^{ \pm} 0 . \\
70^{\mathrm{a}}\end{array}$ \\
\hline 0.40 & $6.23^{ \pm} 0.01^{\mathrm{a}}$ & $118.67^{ \pm} 17.20^{\mathrm{a}}$ & $26.17^{ \pm} 0.39^{\mathrm{a}}$ & $0.42^{ \pm} 0.57^{\mathrm{a}}$ & $5.38^{ \pm} 0.01^{\mathrm{c}}$ & $\begin{array}{l}13.67^{ \pm} 1 . \\
56^{\mathrm{bc}}\end{array}$ \\
\hline
\end{tabular}

Within Column, mean \pm SD with different superscript are significantly different at $\mathrm{P}<0.05$.

There were significant $(\mathrm{P}<0.05)$ fluctuations in values of the haematological indices, Table 2, for haemoglobin $(\mathrm{Hb})$, the lowest value of $4.31^{ \pm} 0.10 \mathrm{~g} / \mathrm{dl}$ was recorded at the highest toxicant concentration of $0.40 \mathrm{ppm}$. The variatin in packed cell volume (PCV) did not show any definite pattern and appears not to be concentration dependent. The lowest concentration of white blood cells (WBC), $91.70^{ \pm} 0.17 \times 10^{9}$ cells $/ \mathrm{L}$ was recorded at the control group, while the highest value of $104.0^{ \pm} 00.00 \times 10^{9}$ cells/L was recorded at Paraquat dichloride concentration of $0.05 \mathrm{ppm}$ and $0.10 \mathrm{ppm}$. The variation in Neutrophil pattern with the highest concentration of $15.00^{ \pm} 0.00 \times 10^{9}$ cells/L was obtained at $0.05 \mathrm{ppm}$ and $0.40 \mathrm{ppm}$ of Paraquat concentration, while the lowest value of $12.000 .00 \times 10^{9}$ cells was obtained at $0.30 \mathrm{ppm}$ concentration of the toxicant. The fluctuation in Neutrophil values could not be said to be concentration dependent as was observed for Hb and WBC. The Lymphocyte values increased with exposure to the toxicant, but did not vary significantly $(p>0.05)$ again at $0.20 \mathrm{ppm}, 0.30 \mathrm{ppm}$ and $0.40 \mathrm{ppm}$ concentrations of Paraquat dichloride.

Table 2: Haematological parameters of fish

\begin{tabular}{|l|l|l|l|l|l|}
\hline $\begin{array}{l}\text { Conc. Of } \\
\text { paraquat } \\
\text { ppm })\end{array}$ & $\begin{array}{l}\mathrm{Hb} \\
(\mathrm{g} / \mathrm{dL})\end{array}$ & $\begin{array}{l}\mathrm{PCV} \\
(\%)\end{array}$ & $\begin{array}{l}\text { WBC } \\
\left(\mathrm{x} 10^{9} \text { cell/L) }\right.\end{array}$ & $\begin{array}{l}\mathrm{N} \\
\left(\mathrm{x} 10^{9} \text { cell/L) }\right.\end{array}$ \\
\hline 0.00 & $9.00^{ \pm} 0.00^{\mathrm{a}}$ & $33.90^{ \pm} 0.17^{\mathrm{a}}$ & $91.70^{ \pm} 0.17^{\mathrm{c}}$ & $14.30^{ \pm} 0.17^{\mathrm{a}}$ & $85.70^{ \pm} 0.17^{\mathrm{ab}}$ \\
\hline 0.05 & $9.80^{ \pm} 0.00^{\mathrm{a}}$ & $31.00^{ \pm} 0.00^{\mathrm{a}}$ & $104.0^{ \pm} 00.00^{\mathrm{a}}$ & $15.00^{ \pm} 0.00^{\mathrm{a}}$ & $85.90^{ \pm} 0.00^{\mathrm{ab}}$ \\
\hline 0.10 & $9.60^{ \pm} 0.00^{\mathrm{a}}$ & $30.00^{ \pm} 0.00^{\mathrm{a}}$ & $104.0^{ \pm} 00.00^{\mathrm{a}}$ & $13.67^{ \pm} 0.17^{\mathrm{ab}}$ & $86.00^{ \pm} 0.00^{\mathrm{ab}}$ \\
\hline 0.20 & $10.50^{ \pm} 0.17^{\mathrm{a}}$ & $92.00^{ \pm} 0.00^{\mathrm{a}}$ & $94.12 .30^{ \pm} 0.17^{\mathrm{b}}$ & $88.30^{ \pm} 0.17^{\mathrm{a}}$ \\
\hline
\end{tabular}


Haematological Effects Of Paraquat Dichloride On Clarias Gariepinus.

\begin{tabular}{|l|l|l|l|l|l|}
\hline 0.30 & $9.50^{ \pm} 0.14^{\mathrm{a}}$ & $31.00^{ \pm} 0.00^{\mathrm{a}}$ & $96.30^{ \pm} 0.30^{\mathrm{ab}}$ & $12.00^{ \pm} 0.00^{\mathrm{b}}$ & $88.30^{ \pm} 0.00^{\mathrm{a}}$ \\
\hline 0.40 & $4.31^{ \pm} 0.10^{\mathrm{a}}$ & $33.60^{ \pm} 0.24^{\mathrm{a}}$ & $93.00^{ \pm} 0.00^{\mathrm{b}}$ & $15.00^{ \pm} 0.00^{\mathrm{a}}$ & $88.30^{ \pm} 0.17^{\mathrm{a}}$ \\
\hline
\end{tabular}

Within column' mean SD with different superscript are significantly different at $\mathrm{P}<0.05$.

Key:

$\mathrm{Hb}=$ Haemoglobin

$\mathrm{PCV}=$ Packed cell volume

$\mathrm{N}=$ Neutrophil

$\mathrm{WBC}=$ White blood cell

L= Lymphocytes

\section{Discussion}

The variations in the water quality parameters of the exposed aquaria were minimal $(\mathrm{P}>0.05)$ and comparable to those of the control experiment. All the values were found to be within the suggested tolerance ranges for warm water fish species (Boyd, 1979). These parameters therefore, may not have caused significant abnormal behavioural and haematological changes in the experimental fish species.

Haematological parameters have often been associated with health indices and are of diagnostic significance in routine clinical evaluation of state of health of fish exposed to toxicants (Atamanalp and Yanik, 2003; Adeyemo, 2005). It has also been noted that responses in fish to stresses are non-specific and enables the fish to cope with the condition and in the maintenance of its homeostatic state. If the stress becomes severe and persistent, the response becomes mal-adaptive and threatens the fish health and wellbeing (Barton, 2002). Significant $(\mathrm{P}<0.05)$ variations were observed in haemoglobin, white blood cells, Neutrophils and lymphocytes of the Clarias gariepinus species on exposure to the various concentrations of Paraquat dichloride during the study.

The decrease in haemoglobin concentration with increase in the concentration of Paraquat dichloride may be due to either induced

Haemolysis arising from the exposure or interference with blood production processes or both. Similar effects have been reported after exposure of fish to various toxicants (Erodu et al, 1993; Adeyemo, 2005 : Gabriel et al., 2009. Also, toxicants could interfere with the osmoregulatoin processes leading to a decrease in plasma osmolarity which is associated with a rise in blood volume and tissue water content, increased influx of water through the gills due to changes in gill permeability of water and failure of electrolyte regulatory mechanisms. Another probable explanation to the observed destruction of blood cells may be the effects of the pesticide on some receptor enzymes (Celik, 2004). These conditions could cause anemia and leucopenia as reported by Luskova et al.(2002). The observed increase in white blood cells (WBC) with increasing concentration of Paraquat dichloride is in consonance with the belief that WBC functions in organisms against foreign bodies, aided by phago- cytosis and antibody production, values will increase as a result of lethalic effects of the toxicant. Similarly, Gabriel et al. (2009) attributed these changes to possible excitation of the defense mechanism of the fish to counter the effect of the toxicant.

Lymphocytes and neutrophils form part of the granulocytes that make up leucocytes (WBC,s) in animals. The pattern of fluctuations observed for the neutroophils, lymplocytes and white blood cells generally due exposure to Paraquat dichloride, may be akin to those of fractionated hydrocarbon products which have been implicated in eliciting excess glucocorticoid, antibody depression, and lymphatic involution, retard the migration of phagocytic leucocytes and alterations of the total white blood cell (WBC) count (kori-Siakpere, (1985): Ayalogu et al. (2001) and Gabriel et al. (2007).

In conclusion, this study has shown that Paraquat dichloride is highly toxic to Clarias gariepinus. The low concentration of Paraquat dichloride that elicited these abnormal changes in the metabolic processes of Clarias gariepinius obviously showed the level of toxicity of the herbicide on organisms. Therefore, paraquat dichloride has been shown to produce changes in biochemical and haematological parameters of Clarias gariepinius. Paraquat dichloride should be used with caution since this chemical will eventually end up either through run- off or leaching into the aquatic ecosystem. This may lead to alterations in the aquatic biosensors, distorting aquatic energy dynamics with the resultant reduction in fishery production within the water body, with potentially unfathomable consequence on the environment and man.

\section{Acknowledgement}

We are grateful to the staff of Federal Medical Centre Laboratories Yenagoa and Niger Delta University Post-graduate Laboratories for assisting with the analysis.

\section{References}

[1]. Adeyemo, O.K.(2005). Haematological and histopathological effects of cassava mill effluent on Clarias gariepinus. Afri .J. biomed. Res. 8(3):179-183).

[2]. American public Health Association (APHA). (1998). Standard methods for the Evaluation of water and waste water. 20 ${ }^{\text {th. }}$ Ed. Washington, DC: American Public Health.

[3]. Atamanalp, M. Yanik, T.(2003). Alteration in hematological parameters of rainbow trout (Oncorhyrichius mykiss) exposed to mancozeb. Turk. J.Vet. Anim.Sci. 27: 1213-1217. 
[4]. Ayalogu, O.E: Igboh, N.M.Dede, E.B.(2001). Biochemical changes in the serum and liver of albino rats exposedto petroleum samples (gasoline, kerosene and crude petroleum). J.Appl. Sci. Environs. Manage. 5(1):97-100.

[5]. Barton, A.B. (2002). Stress in fishes: a diversity of responses with particular reference to changes in circulating corticosteroids. Integer. Comp. biol. 42:

[6]. Boyd, C.E. (1979). Water quality in warm water fish ponds. Alabama Agricultural Rearch station, Alabama,USA. Pp: 362. Das, B.K and S.C. mukherjee (200). Sublethal Effects of Quinalphos on selected blood parameters of Labeo rohita (HAM) fingerlings. Asian fish Sci 13:225-233.

[7]. Celik, E.S.(2004). Blood chemistry (electrohytes, lipoproteins and enzymes) values of black scorpion fish (scorpaena porcus) in the Dardenelles. Turkey J. Biol. Sci: 4 (4): 716-719.

[8]. Erondu, E.S, Nnubia, C and Nwadukwe, O.(1993). Haematological studies on four catfish species raised in freshwater ponds in Nigeria. Jourinal of Applied Ichthyology: 9;250-256.

[9]. Gabriel U.U. Amakiri, N.E. Ezeri, G.N.O. (2007).Haematology and gill pathology of Clarias gariepinus exposed to refined petroleum oil, kerosene under laboratory conditions. J. Anim. Vet. Advances 6 (3): 461 - 465.

[10]. Gabriel, U.U., Obomanu, F.G. and Edoric, 0.5 (2009). Haematology, plasma enzymes and organ indices of Clarias gariepinus after intramuscular injection with aqueous leaves extracts of lepida-gathis alopecuroides. Afri Journ, of Biochen. Res Vol.3(9), pp. 312 316.

[11]. Ita, E.O. (1980). A Review of recent advance in warm water Aquaculture resources and a proposed experimental design for maximizing fish production in Nigeria K.L.R.I. Technical Rep Series, 51:30.

[12]. Kori - Siakpere, O.(1985). Haematological characteristics of Clarias isheriiensis Sydenham. Jourmal of fish Biology 263.

[13]. Patnaik, L; and A.K. Patra (2006). Haematopoeitic Alterations Induced by carbonyl in Clarias batrachus (Linn). J. Appled Sci. Environ Manage; 10:5 - 7 .

[14]. Luskova, V; Svoboda, M. , Kolarova, J. (2002). The effects of Diazinon on blood plasma biochemistry in carp (Cyprinus carpio) Act. Vel. BRNO 71: 117 - 125 .

[15]. Svobodova, Z; Pravda, D. and palackova J. (1991). Unified methods of haematological examination of fish.Vodeny, Czechoslovakia: Research Institute of fish culture and Hydrobiology, 31pp.

[16]. Wahua, T.A.T. (1999). Applied statistics for scientific studies. African Link Books, Aba, Nigeria, P. 365. 